\title{
Solvent Extraction and Evaluation of Antifungal Activity of Muntingia calabura Root against Fungal Phytopathogens
}

\section{Rajesh Ramasamy ${ }^{*}$, Jaivel Nanjundan and Marimuthu Ponnusamy}

\author{
Department of Agricultural Microbiology, Tamil Nadu Agricultural University, \\ Coimbatore 641 003, Tamil Nadu, India \\ *Corresponding author
}

\begin{tabular}{|c|c|}
\hline \multicolumn{2}{|c|}{ A B S T R A C T } \\
\hline & The aim of the present study is to determine the in vitro antimicrobial activity of \\
\hline Keywords & $\begin{array}{l}\text { various extracts of Muntingia calabura (Elaeocarpaceae) leaves against a selected } \\
\text { panel of microorganisms. Antimicrobial testing was carried out using the agar well }\end{array}$ \\
\hline $\begin{array}{l}\text { Muntingia } \\
\text { calabura, } \\
\text { Antifungal, Agar } \\
\text { well diffusion, } \\
\text { Fungal pathogen, } \\
\text { MIC. }\end{array}$ & $\begin{array}{l}\text { diffusion assay method. The microbes targeted were A. solani, Fusarium } \\
\text { oxysporum f.sp lycopersici, Pythium sp., Phytophthora sp., Rhizoctonia solani, } \\
\text { Aspergillus niger and Colletotrichum sp. Results of this study showed that the } \\
\text { methanol leaf extract of } M \text {. calabura was effective against A. solani, Fusarium } \\
\text { oxysporum f.sp lycopersici, Pythium sp., Phytophthora sp., Rhizoctonia solani, }\end{array}$ \\
\hline Article Info & Aspergillus niger and Colletotrichum sp. with inhibition zone of 2.3, 2.0, 2.0, 1.8, \\
\hline $\begin{array}{l}\text { Accepted: } \\
\text { 04 June } 2017 \\
\text { Available Online: } \\
\text { 10 July } 2017\end{array}$ & $\begin{array}{l}\text { Finally, it is concluded that } M \text {. calabura possesses a potential antifungal property } \\
\text { and the results also suggested the presence of more potent polar antifungal } \\
\text { compound in the Muntingia calabura plant material. }\end{array}$ \\
\hline
\end{tabular}

\section{Introduction}

Muntingia calabura L. (Kerukupsiam), also known locally as Jamaica cherry, is a plant of the family Elaeocarpaceae (Morton, 1987). It is native to the American continent and is widely cultivated in warm areas of Asian region, including Malaysia (Chin, 1989).

Its leaves, barks and flowers are believed to possess medicinal value as reported in Peru folklore medicinal uses. Various parts of this tree have several documented medicinal uses in both Southeast Asia and tropical America (Nshimo et al., 1993). The roots have been employed as an emmenogogue in Vietnam and as an abortifacient in Malaysia. In the Philippines, the flowers of this species have been used to treat headaches, and as an antidyspeptic, antispasmodic and diaphoretic. Infusions of the flowers of this plant are drunk as a tranquillizer and tonic in Colombia (Kaneda et al., 1991).

In addition, the $M$. calabura leaves extracts also possesses antibacterial activity (Zakaria et al., 2006) and antistaphyloccocal activity (Zakaria et al., 2007). Since antiquity, man has used plants to treat common infectious diseases and some of these traditional 
medicines are still included as part of the habitual treatment of various maladies. Crude extracts of some well-known medicinal plants are used to control the plant pathogens. During the past few years, there is a growing trend all over the world to shift from synthetic to natural products including medicinal plants (Parimaladevi and Marimuthu, 2011). In this study the methanol, chloroform and petroleum ether extracts of $M$. calabura root is screened against selected fungal pathogens for the presence of antifungal activity using the agar well diffusion assay method.

\section{Materials and Methods}

\section{Plant materials}

The plant samples taken for this study were collected from Eastern Block Farm in Tamil Nadu Agricultural University, Coimbatore-3. The plant sample, obtained after initial screening studies performed against fungal pathogens was identified and certified through Botanical Survey of India (BSI), TNAU, Coimbatore -3, Tamil Nadu.

\section{Preparation of $M$. calabura root extracts}

The dried and powdered plant samples root were extracted by percolation with methanol, chloroform and petroleum ether at the rate of 1:5 at room temperature for overnight. The extracts were then filtered with country filter paper and concentrated under vaccum in a rotary evaporator to get 6-11 per cent of gummy residue as a percentage of powdered plant materials. All the extracts were kept in a tightly stoppered bottle in a refrigerator. All the extracts then assayed for antimicrobial activity.

\section{Microorganisms tested}

Microorganisms tested in this study were Alternaria solani (Ell. and Mart.) Jones and Grout, Fusarium oxysporum f.sp. lycopersici
W.C. Snyder and H. N. Hansen, Pythium sp., Phytophthora sp., Rhizoctonia solani J.G. Khunn, Aspergillus niger Van Tiegham and Colletotrichum sp.

\section{Antimicrobial screening}

The sterilized medium seeded with respective fungal pathogen was poured into the petriplates and allowed to solidify. Then each petriplate was divided into four equal quarters using a marker pen. Using a sterile cork borer, wells of $6 \mathrm{~mm}$ in diameter were made in each quadrat of the plate containing the media. For each organism, $20 \mu \mathrm{l}$ of the prepared plant sample was loaded in each well. Two replications were maintained for each treatment. For each test pathogen, the positive control and the negative control (two replications each) were also loaded in a separate well. The plates were incubated for $24 \mathrm{~h}$ and the observations were taken. The observations were made by measuring the inhibition zone (or halo like area), which indicates the absence of microbial growth around the well. The diameter of inhibition zone (DIZ) was measured and the mean DIZ was calculated.

\section{Determination of Minimum Inhibitory Concentration (MIC)}

The MIC assay was performed to test the antimicrobial activity of the methanol extract of $M$. calabura root using tube dilution method (Claeys et al., 1988). The MIC was defined as the lowest concentration of antibiotics or plant extracts that did not show any growth of tested pathogens. This test was performed at four concentrations of the plant extract viz., 10 $\mathrm{mg} / \mathrm{ml}, 1 \mathrm{mg} / \mathrm{ml}, 0.1 \mathrm{mg} / \mathrm{ml}$ and $0.01 \mathrm{mg} / \mathrm{ml}$.

\section{Results and Discussion}

Based on the experiment conducted in the Microbiology lab, TNAU, Coimbatore, Muntingia calabura is significant as the 
potential source for the control of plant pathogens. The medicinal plant sample Muntingia calabura Linn., was identified and certified through Botanical Survey of India, Tamil Nadu Agricultural University, Coimbatore for confirmation of the genus and species (Plate 2). The present study was aimed at evaluating the antimicrobial property of $M$. calabura root extract against fungal pathogens.

The antimicrobial compounds from the root of M. calabura were extracted separately by using three different solvents viz., methanol (polar), chloroform (medium polar) and petroleum ether (least polar). The results of the studies on antimicrobial activity against fungal pathogens revealed that the methanol extract of $M$. calabura possessed broad spectrum of antimicrobial activity compared to other solvent extracts.

\section{Determination of different solvent extracts of $M$. calabura root against fungal pathogens}

The methanol extract of $M$. calabura root possessed more inhibitory activity against $A$. solani, Fusarium oxysporum f.sp lycopersici, Pythium sp., Phytophthora sp., Rhizoctonia solani, Aspergillus niger and Colletotrichum sp. The methanol extract of $M$. calabura root was found to inhibit the pathogens more effectively than the chloroform and petroleum ether extracts. The diameter of inhibition zones produced by the methanol extract of $M$. calabura against $A$. solani- $2.3 \mathrm{~cm}, F$. oxysporum f.sp. lycopersici- $2.0 \mathrm{~cm}$, Pythium sp. - $2.0 \mathrm{~cm}$ and Phytophthora sp. $-1.8 \mathrm{~cm}$, Rhizoctonia solani- $1.5 \mathrm{~cm}$, Aspergillus niger - $1.6 \mathrm{~cm}$ and Colletotrichum sp. - $1.7 \mathrm{~cm}$ respectively. Whereas chloroform extract showed inhibition zone of $1.5 \mathrm{~cm}$ for both $A$. solani and $F$. oxysporum f.sp. lycopersici. In case of petroleum ether extract the inhibition zone was found to be $1.0 \mathrm{~cm}$ for $A$. solani and
$0.7 \mathrm{~cm}$ for $F$. oxysporum f.sp. lycopersici. The positive control ketoconazole showed the highest activity of 3.5, 3.0, 2.8, 3.0, 3.2, 3.5 and $2.9 \mathrm{~cm}$ of inhibition against $A$. solani, $F$. oxysporum f.sp. lycopersici, Pythium sp., Phytophthora sp., Rhizoctonia solani, Aspergillus niger and Colletotrichum sp. (Table 1).

In the present study, Muntingia calabura root was tested for its antimicrobial activity by agar well diffusion assay against selected fungal pathogens. Based on the results, the methanol extract of Muntingia calabura was considered to be the most active extract than compared to chloroform extract and petroleum ether extract. Since many years, medicinal plants have been used extensively as sources for the study and research on active compounds against several bacterial strains. Parimaladevi (2008) reported that the chloroform extract of Polygonum minus exhibited antimicrobial activity against $A$. solani, Fusarium oxysporum f.sp lycopersici and $A$. niger under in vitro condition. Ram Kumar et al., (2010) reported the antibacterial effect of Syzygium aromaticum and Allium sativum against food borne microorganisms. Omojasola and Awe (2004) reported the antibacterial activity of leaf extract of Anacardium occidentale and Gossypium hirsutum against Staphylococcus aureus, E. coli and P. aeruginosa. Khalid et al., (2010) reported the Achillea fragrantissima antibacterial activity of these extracts against several numbers of bacterial pathogens.

The hydroalcoholic (80\% ethanol) extract of Plumbago indica roots exhibited antibacterial activity against Staphylococcus aureus, $P$. aeruginosa, E. coli and Bacillus subtilis (Valsaraj et al., 1997). Some plants may be alternatives to currently used disease control agents, since they constitute a rich source of bioactive chemicals (Swain 1977; Wink 1993). The substances, which can either inhibit the 
growth of pathogens or kill them and have no or least toxicity to host cells are considered as candidates for developing new antimicrobial drugs (Waccaro et al., 1996).

Plate.1 Antimicrobial activity of methanol extract of $M$. calabura root against fungal plant pathogens by agar well diffusion assay

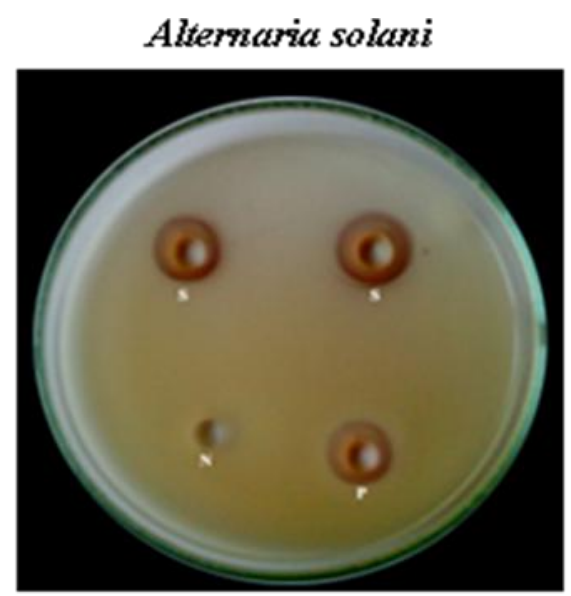

\section{Fusarium oxysporum f.sp. bycopersici}

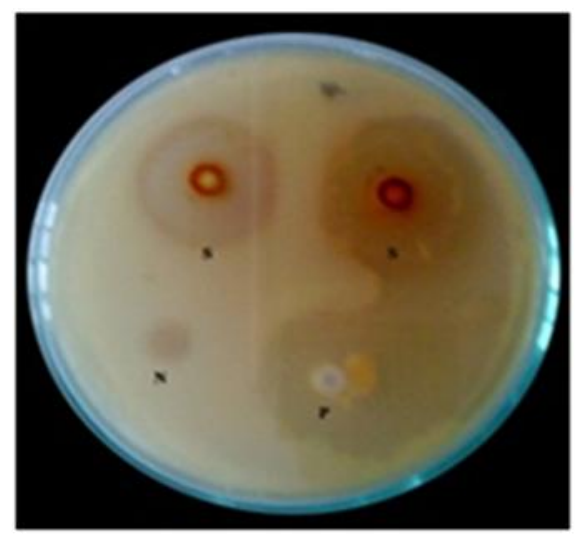

Pythium sp.

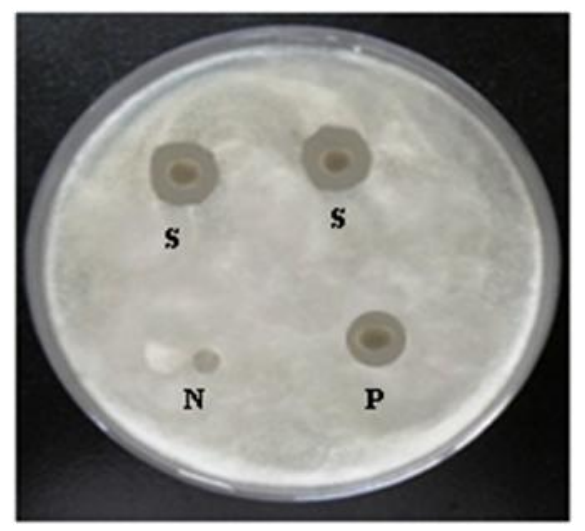

S - Sample (Methanol extract of $M$. calabure root)

$P$ - Positive control (Ketocon azole)

$\mathrm{N}$ - Negative control (E thanol 100\%) 
Int.J.Curr.Microbiol.App.Sci (2017) 6(7): 77-83

Table.1 Antimicrobial activity of Muntingia calabura root extract against fungal plant pathogens

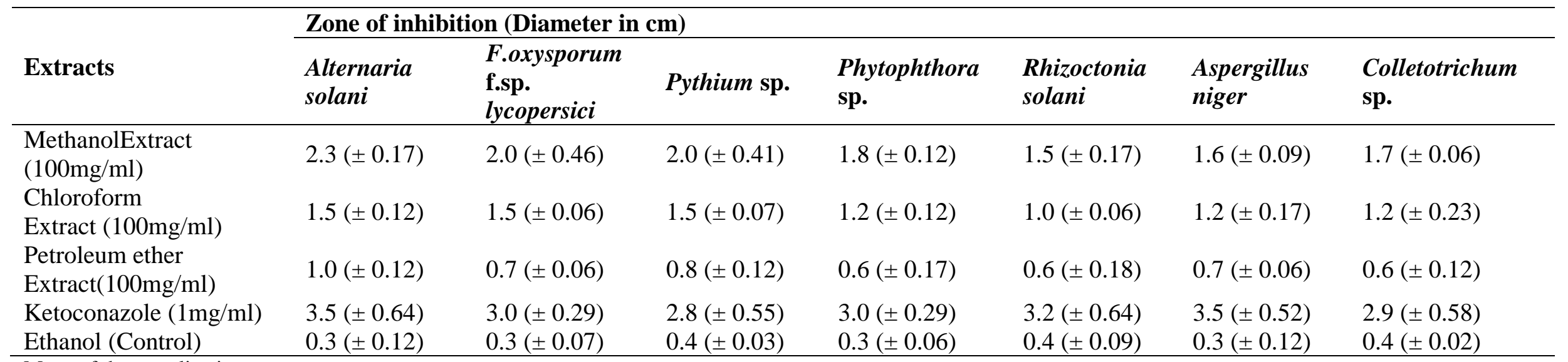

Mean of three replications

Table.2 Minimum inhibitory concentration of methanol extract of M. calabura root against fungal plant pathogens

\begin{tabular}{|c|c|c|c|c|c|c|c|}
\hline \multirow[b]{2}{*}{ Extracts } & \multicolumn{7}{|c|}{ Fungal plant pathogens } \\
\hline & $\begin{array}{l}\text { Alternaria } \\
\text { solani }\end{array}$ & $\begin{array}{l}\text { F.oxysporum f.sp. } \\
\text { lycopersici }\end{array}$ & $\begin{array}{l}\text { Pythium } \\
\text { sp. }\end{array}$ & $\begin{array}{l}\text { Phytophthora } \\
\text { sp. }\end{array}$ & $\begin{array}{l}\text { Rhizoctonia } \\
\text { solani }\end{array}$ & $\begin{array}{l}\text { Aspergillus } \\
\text { niger }\end{array}$ & Colletotrichum sp \\
\hline \multicolumn{8}{|l|}{ MethanolExtract } \\
\hline $10 \mathrm{mg} / \mathrm{ml}$ & - & - & - & - & + & + & + \\
\hline $1 \mathrm{mg} / \mathrm{ml}$ & + & + & + & + & + & + & + \\
\hline $0.1 \mathrm{mg} / \mathrm{ml}$ & + & + & + & + & + & + & + \\
\hline $0.01 \mathrm{mg} / \mathrm{ml}$ & + & + & + & + & + & + & + \\
\hline \multicolumn{8}{|l|}{ Ketoconazole } \\
\hline $10 \mathrm{mg} / \mathrm{ml}$ & - & - & - & - & - & - & - \\
\hline $1 \mathrm{mg} / \mathrm{ml}$ & - & - & - & - & - & - & - \\
\hline $0.1 \mathrm{mg} / \mathrm{ml}$ & + & + & + & + & + & + & + \\
\hline $0.01 \mathrm{mg} / \mathrm{ml}$ & + & + & + & + & + & + & + \\
\hline Solvent control & + & + & + & + & + & + & + \\
\hline Cells & + & + & + & + & + & + & + \\
\hline
\end{tabular}


Minimum inhibitory concentration of methanol root extract of $M$. calabura against fungal pathogens

The minimum inhibitory concentration was evaluated for the methanol root extract of $M$. calabura against the selected pathogenic cultures viz., A. solani, Fusarium oxysporum f.sp lycopersici, Pythium sp., Phytophthora sp., Rhizoctonia solani, Aspergillus niger and Colletotrichum sp. The results of the minimum inhibitory concentration assay of the methanol root extract of $M$. calabura indicated that the extract inhibited the growth against A. solani, Fusarium oxysporum f.sp lycopersici, Pythium sp., Phytophthora sp., Rhizoctonia solani, Aspergillus niger and Colletotrichum sp. at a concentration of 10 $\mathrm{mg} / \mathrm{ml}$ (Table 2), whereas growth was observed in the other three dilutions/concentrations (1 $\mathrm{mg} / \mathrm{ml}, \quad 0.1 \quad \mathrm{mg} / \mathrm{ml}$ and $0.01 \quad \mathrm{mg} / \mathrm{ml}$ ). Chloramphenicol (positive control) showed no growth at $10 \mathrm{mg} / \mathrm{ml}$ and $1 \mathrm{mg} / \mathrm{ml}$ concentrations, but growth was observed in the other two dilutions. The cells and solvent control (negative control) showed growth in all the dilutions for all the organisms. Methanol extract of Aeglema rmelos showed MIC at 5\% (w/v) level against Alternaria solani, Fusarium moniliforme and Pythium sp. and methanolic extracts of Achillea fragrantissima possessed the MIC of $1.2-2.9 \mathrm{mg} \mathrm{mL}^{-1}$ against $E$. coli and $P$. aeruginosa (Khalid et al., 2010). Negi and Jayaprakasha, (2001) reported that the ethyl acetate extract of kaffir lime (Citrus hystrix DC.) peel showed minimum inhibitory concentration (MIC) values of 0.28 and 0.56 $\mathrm{mg} / \mathrm{ml}$ against $S$. cerevisiae var. Sake and $B$. cereus, respectively. Khalid et al., (2010) reported that the minimum inhibitory concentration of Teucrium polium against Staphylococcus aureus, E. coli and $P$. aeruginosa was $2 \mathrm{mg} \mathrm{mL}^{-1}$. In the present study, the minimum inhibitory concentration of methanol extract of $M$. calabura root was found to be $10 \mathrm{mg} / \mathrm{ml}$ against the tested pathogens. In conclusion, the present study has revealed the antimicrobial activity of $M$. calabura root extracts against selected human pathogens. Further investigations are needed to characterize the active compounds in order to determine the structure and antimicrobial potential under in vivo studies.

In conclusion the medicinal plant Muntingia calabura was chosen for the study to test the antimicrobial activity against fungal pathogens. The root extracts of the medicinal plant were assessed for their antimicrobial activity. The antimicrobial compounds of the medicinal plants were extracted with three different solvents viz., methanol, chloroform and petroleum ether of varying polarity. The extracts were filtered using Whatmann No. 44 filter paper and concentrated using a rotary vacuum evaporator to get 6-11 per cent of gummy residue. Antimicrobial activities of the M. calabura root were tested against the selected fungal pathogens by agar well diffusion assay.

\section{References}

Chin, W.Y. 1989. A guide to the wayside trees of Singapore. BP Singapore Science Centre p: 145.

Claeys, M.L., Pieters. J., Corthout, D.A., B. Vanden and Vlietinck, A.J. 1988. A new antimicrobially active flavonoid from Lantann atrifolia. J. Nat. Prod. 51: 966-968.

Czygan, F.C. 1993. Kulturgeschicte and mystik des johanniskrautes. Zeitsch. Phytother. 5: 276-282.

Eloff, J.N. 1998. Sensitive and quick microplate method to determine the minimal inhibitory concentration of plant extracts for bacteria. Plant Med. 64: 711-713.

Hamburger, M. and K. Hostettmann. 1991. Bioactivity in plants: the link between phytochemistry and medicine. Phytochem. 30: 3804-3814.

Joy, M., John, J., K.P. Smitha and Nair, R.V. 2004. Inhibitory effects of cashew 
(Anacardium occidentale L.) on phytopathogenic fungi. Allelopat. J., 13: 47-56.

Kaneda, N., Pezzuto, J.M, Soejarto, D.D., Kinghorn, A.D., Farnwort, N.R., Santisuk, T., Tuchinda, P., J. Udchachon and Reutrakul. V. 1991. Plant anticancer agents, XLVII.New cytotoxic flavanoids from Muntingia calabura roots. J. Nat. Prod. 54:196-206.

Khalid, A.T, Fawzi, I, Adnan, S.J, E. Magda and Khaled, M.K. 2010. Evaluation of antibacterial and antioxidant activities of methanolic extracts of some medicinal plants in northern part of Jordan. J. Biol. Sci. 10: 325-332.

Morton, J.F. 1987. Jamaica cherry. In: Fruits of warm climates. Julia. F. Morton., pp 65-69.

Negi, P.S. and Jayaprakasha, G.K. 2001. Antibacterial activity of grapefruit (Citrus paradisi) peel extracts. Eur. Food Res. Technol. 213: 484-487.

Nshimo, C.M, Pezzuto, J.M, A.D. Kinghorn and Farnsworth.N.R. 1993. Cytotoxic constituents of Muntingia calabura leaves and stems collected in Thailand. Int. J. Pharmacol. 31:77-81.

Ody, P. 1993. The complete medicinal herbal. Dorling Kindersley limited, New York, pp: 132-171.

Omojasola, P.F. and Awe, S. 2004. The antibacterial activity of the leaf extracts of Anacardium occidentale and Gossypium inisutum against some selected microorganisms. Biosci. Res. Comm. 16: 25-28.

Parimaladevi, R. 2008. Screening and isolation of antimicrobial compounds from medicinal plants against plant diseases. Ph.D. Thesis. Tamil Nadu Agricultural University, Coimbatore.
Parimaladevi, R. and Marimuthu, P. 2011. Effect of botanical formulation of polygonum minus on control of Alternaria solani. J. Plant Pathol. Microbiol., 2: 1-4.

Ram Kumar, P.P., P. Jain and Sharma. C. 2010. Antimicrobial activity of ethanolic extracts of Syzygium aromaticum and Allium sativum against food associated bacteria and fungi. Ethno botanical Leaflets. 14: 344-360.

Siva, N., Ganesan, S, N. Banumathy and Muthuchelian, K.2008. Antifungal effect of leaf extract of some medicinal plants against Fusarium oxysporum causing wilt disease of Solanum melongena L. Ethno botanical Leaflets, 12:156-163.

Swain, T. 1977. Secondary compounds as protective agents. Annu. Rev. Plant Physiol., 28: 479-501.

Valsaraj, R., Pushpangadan, P, Smitt, U.W, A. Adsersen and Christensen, S.B, 1997. New anti-HIV-1, antimalarial, and antifungal compounds from Terminalia bellerica. J. Nat. Prod. 60: 739-742.

Wink, M. 1993. Production and application of phytochemicals from an agricultural perspective. Phytochemistry and agriculture. Oxford, United Kingdom Clarendon Press. p. 171-213.

Zakaria, Z.A., Fatimah. C.A, Jais, A.M.M, Zaiton, H, Henie, E.F.P, Sulaiman, M.R, Somchit, M.N, M. Thenamutha and Kasthuri, D. 2006. The in vitro antibacterial activity of Muntingia calabura extracts. Int. J. Pharmacol. 2(4): 439-442.

Zakaria, Z.A., Jais, A.M.M, M. Mastura and Jusoh, S.H.M. 2007. In vitro antistaphylococcal activity of the extracts of several neglected plants in Malaysia. Int. J. Pharmcol, 3: 428-431.

\section{How to cite this article:}

Rajesh Ramasamy, Jaivel Nanjundan and Marimuthu Ponnusamy. 2017. Solvent Extraction and Evaluation of Antifungal Activity of Muntingia calabura Root against Fungal Phytopathogens. Int.J.Curr.Microbiol.App.Sci. 6(7): 77-83. doi: https://doi.org/10.20546/ijcmas.2017.607.009 